\title{
Technology as a platform for intercultural communication exemplified by the migration from Africa and the Middle East
}

Streszczenie: Tekst dotyczy możliwości komunikacji międzykulturowej, jakie dają współczesne media cyfrowe. Analizuje możliwości jej rozwoju na przykładzie problemu masowej migracji do Europy. Dotyczy ona krajów, które są często dużo słabiej ekonomicznie rozwinięte niż kraje Europy czy Ameryki. Jak pokazują jednak dane dotyczące rozwoju technologii w tych krajach czy jej wykorzystania (np. w masowych ruchach społecznych z przełomu pierwszej i drugiej dekady XXI w.), obywatele tych krajów nie są „cyfrowymi analfabetami”. Podobnie jest z migrantami przybywającymi z tych krajów. Dlatego media cyfrowe, a szczególnie takie narzędzia jak smartfony, mogą być wykorzystane w międzykulturowym dialogu oraz pomocy migrantom na różnych etapach ich migracyjnej wędrówki. Dotyczy to zwłaszcza etapu podejmowania decyzji, wędrówki do wybranego kraju czy aklimatyzacji w kraju docelowym. Powstało szereg takich pomocy (przede wszystkim aplikacji na smartfony), które jednak nie dotyczą w równym stopniu wszystkich trzech etapów życia migranta.

Słowa kluczowe: nowe technologie, migracja, komunikacja międzykulturowa, smartfon

For several years, televisions from around the world have been showing rising from time to time waves of immigrants heading towards Europe or already moving across the continent. They are people of different languages, races, religions, usually tired and hungry. It is difficult for European services to communicate with them and control them. The process of integration of migrants is also often very long and takes years ${ }^{1}$.

What is characteristic, however, many of them have smartphones and tablets, as well as profiles on social networking sites. In this way, they keep in touch with their families and with each other on their way to Europe. This

1 What is the suggestive story of the Swedish documentary film: "The Swedish Theory of Love" directed by E. Gandini, Sweden 2015. 
digital aspect of migration was quickly recognised and used. Migrants usually did not have knowledge of the language of the country they came to, but were able to do e.g. selfies. German Chancellor Angela Merkel made a great use of it, which during various meetings with migrants allowed her to take hundreds of selfies in the lead role ${ }^{2}$. Many of these photos, however, brought a lot of confusion to both the Chancellor and immigrants taking selfies. After the terrorist attacks in Brussels, the media decided, based on a selfie available on social networks, that one of the bombers was a Syrian who had taken a selfie with Merkel several months earlier. Although this turned out to be untrue, the information began to live its life (Fenton, 2016). Technology becomes a plane where despite the distance of cultures one can communicate in an understandable language.

\section{New digital communication paradigms}

The development of technology is progressing very quickly. The social changes it causes are often hard to predict. We begin to notice them when they appear, not always bearing fruit adequate to the intended ones. This was the case with the development of the Internet, when it was forecasted at the beginning of the 1990s that it would become a kind of info-highway, giving completely new possibilities of knowledge development. At the end of the decade, it was necessary at various levels (legal, social and educational) to protect children and young people against the negative effects of network development. Similarly, we are not able to fully predict what social changes will bring the development of the "Internet of Things" in the near future.

It is no wonder then that the paradigms adopted in the course of research on new communication technologies are also evolving and are even being questioned and replaced by others. Even a decade ago, the terms "digital natives", "digital immigrants" and "digital exclusion" were widely used. In the beginning, these terms were used in a demographic sense. A digital divide has been suggested between the generation of children and parents and

2 Some examples: https://www.thelocal.de/20190717/angela-merkel-at-65-10-photos-that-tell-the-story-of-germanys-eternal-chancellor; https://www.infomigrants.net/ en/post/11442/refugees-integrating-into-german-jobs-market-says-agency; https:// www.alamy.com/berlin-germany-18-august-2019-federal-chancellor-angela-merkelr-cdu-is-doing-a-selfie-with-a-young-girl-during-the-federal-governments-openday-photo-michael-kappelerdpa-credit-dpa-picture-alliancealamy-live-news-image264451153.html. 
grandparents. The former were to be specialists in new technologies, moving around their world in a completely free and natural way (Gorman, McLean, 2010). Unlike them, for digital immigrants it was a completely alien world in which it was difficult for them to find themselves and many did not even make attempts in this regard. In addition, the existence of entire groups of people (e.g. old people and people from small towns) covered by the so-called digital exclusion; people not only not knowing about new technologies, but not even aware of their existence and meaning.

In addition to demographic exclusion, there was also geographical exclusion. Economic and technological differences meant that access to the Internet and mobile telephony in many parts of the world was more difficult and much more expensive than in Europe and North America (M. Lister, J. Dovey, S. Giddinas, I Grant, K. Kelly, 2009). In 2010, only $2 \%$ people in Africa had access to broadband internet ${ }^{3}$.

Digital exclusion, both demographic and geographical, is slowly becoming a thing of the past. A generation of parents, for whom the natural environment in which they were growing up was the environment of new technologies, has grown up. The Internet of Things is still more tightly filling the immediate surrounding of people with devices connected to the network. The situation is similar in the geographical aspect. As for the increase in internet coverage and access to mobile telephony, we observe the largest dynamics on emerging markets in the region of Southeast Asia, the Middle East or Africa. This often exceeds the forecasts from previous years. In the years 2011-2013, the increase in the access to broadband internet in developing countries doubled. But for example in the case of Africa, this increase was more than fivefold (from 2 to $11 \%)^{4}$. When in 2006 a significant increase in sales of mobile phones was recorded, it also concerned "emerging markets" .

Africa is the best example of the dynamic development of digital communication due to the fact that for many years there was the greatest backwardness. Even in the least developed countries, such as Chad or Somalia, in three years (2013-2016) there was an almost twenty-fold increase in active mobile phones. Africans do not want to be just consumers of new technologies.

3 Source: International Telecommunication Union. https://www.facebook.com/10 3018419782973/posts/430972763654202 (02.01.20).

4 Source: International Telecommunication Union. https://www.facebook.com /103018419782973/posts/430972763654202 (02.01.20).

5 Source: Computerworld. https://www.computerworld.pl/news/Miliard-telefo now-w-2006-r,105709.html (02.01.2020). 
They want to create equivalents of the Silicon Valley in the Dark Continent. Before the Africa Digital Awards in Accra (Ghana), in June 2019, Thomas Mensah, head of the Silicon Valley of Ghana, declared that 300,000 secondary school students will undergo training in software development. According to the creator of this programme, innovation centres can become business development accelerators. Ghana is an example of the ambitions of African countries trying to reduce the distance to the largest "digital powers" and even offer competitive products (Nyavi, 2019). The very organisation of the annual event gathering African specialists in technological innovation shows how strong is the attitude on the Dark Continent in terms of introducing innovations and discovering current trends, and an increasingly better understanding of the challenges facing digital Africa (Kuuire, 2019).

Another example of the development of innovative technologies is the activities of Mara Corporation. The company operates in 24 countries, of which 22 are African countries. One of the directions of its development are new technologies. Mara Corporation has its own factories, among others in Rwanda, Egypt, Algeria and Durban, the largest port of South Africa. It is also piloting the introduction of new technologies in Africa (including $5 \mathrm{G}$ technology). It was in the Rwandan factory that the first smartphone made entirely in Africa and from African parts debuted in October 2019. The phone in two versions (Mara X and Mara $\mathrm{Z}$ ) is equipped with the Android operating system and is to be inexpensive (Shapshak, 2019). New phones are promoted with the slogan "Made in Africa". Their price can make them an attractive and desirable model also outside Africa ${ }^{6}$.

Mara Corporation is undoubtedly the leading hi-tech company in Africa. Not in all countries this development is even. But we can talk about a kind of "digital awakening" of Africa. The dynamics of this process somewhat surprised some. Somehow, the words of Pope Benedict XVI from the Message for the World Social Communications Day in 2009 are fulfilled: "These technologies are a real gift for humanity. We must therefore make them available to all people and communities, especially the needy and defenceless" (Benedict XVI, 2009). The common perception of Europeans and Americans about technology in African countries, southern Asia or the Middle East must also change. People living in these regions of the world are no longer "digital illiterates." Digital technologies are an understandable and eagerly

6 Mara Corporation has launched a special site presenting the Mara X and Mara $\mathrm{Z}$ models, https://maraphones.com. 
used communication channel for them. They will probably lead to significant social changes in the near future, the beginnings of which can already be observed. E-democracy is developing its wings based on digital platforms. For now, this is still happening in a rather spontaneous and uncoordinated manner, but governments and international organisations have to reckon with this. The key issue here is access to the right channel, which is becoming easier (Lee, 2006).

\section{Digital citizens. Opportunities and threats}

Thanks to their communication capabilities, digital technologies can become a way to empower people, especially in those parts of the world where there are big problems with the functioning of direct democracy. That the digital media are becoming the basic communication platform in Africa and the Middle East has been shown by the events of the so-called Arab Spring. It is a series of social outbreaks and armed conflicts in the Arab countries of North Africa and the Arabian Peninsula at the turn of the first and second decades of the 21st century. However, Manuel Castells estimates that despite the fact that digital media played a key role in this movement, the space of freedom was hybrid. It was co-created not only on social-media accounts and social networking sites, but also by occupying urban space. There were also other spatially engaging initiatives, such as freedom caravans in Tunisia (Castells, 2013). In the days of the outbreak of the revolution, Tunisia had a high rate of access to digital media. In 2010, 67\% of the country's population had a mobile phone and $37 \%$ had access to the Internet. At the beginning of 2011, $20 \%$ of users had a Facebook account (Castells, 2013, p. 41).

In Egypt, the outbreak of social discontent began with an event in the real world. It was a strike at the textile factory in Al-Mahalla al-Kubra on April 6, 2008. But the strike was quickly suppressed and all this movement would probably collapse if it did not survive on the net. The April 6 Youth Movement profile was quickly created on Facebook, which earned 70,000 of likes. Thanks to this, the movement gained considerable popularity, but the unconsidered actions of the managers of social accounts also facilitated the actions of the police, which through it tracked many active members of the movement (Wolman, 2014).

Egypt's rulers quickly understood the power of this movement and quickly restricted access to the network. They even tried to cut off all of Egypt from the Internet. The ability to send messages using mobile phones was also 
quickly reduced. The authorities proceeded in a simple and decisive way by giving orders to the four largest Internet providers and mobile network operators (Castells, 2013).

Also at the time of social unrest in Iran, digital media played a major role. To a large extent, the protests were possible thanks to them. The awareness of their significance was so strong that Iranian outbreaks were even called the "Twitter revolution" (Aboujaoude, 2012, p. 18).

Because of their power, which is not easily controlled, digital media has targeted many governments. Turkish Prime Minister Recep Erdoğan is one of the leaders of the actions taken against them. When speaking against protesters, on March 20, 2014, he explicitly declared that he "will eradicate Twitter" (Orhan, 2017, p. 127). Twitter quickly learned that these words were not thrown into the wind, it was blocked in Turkey. Soon the same thing happened to YouTube. The Supreme Court found such actions unlawful (Łuszczek, 2015).

However, the power of digital media can be used quite differently. Islamic terrorists use them as a tool in a variety of actions. They appreciated the power of these media after the 2001 attacks on the United States. Arab Television $\mathrm{Al}$ Jazeera multiplied the propagandistic power of these attacks on a global scale. With the development of digital media, the possibilities for their use by terrorists have increased significantly. Moreover, the effects of these operations are not limited to Islamic countries, but are directed to Western countries. "Virtual jihad" was born in Europe and not in Islamic countries (Wawrzyńczak, 2014).

Islamists use different tools. They want to fight the West not only by force but also by arguments. That is why the Islamic State began publishing the magazine "Dabiq" in English in 2014. Appearing on the Internet in the PDF format, it was addressed primarily to Westerners to convince them to Islamist ideology (Kibble, 2016). After the Islamic State began to shrink geographically under the pressure of the coalition troops, it also began to shrink digitally and "Dabiq" (which since 2016 has been published under the title "Rumiyah") is already difficult to access on the Internet. According to Remy Mahzam, "Rumiyah" aims to reach three groups of people: ISIS fighters, environment that support Islamists and sympathisers. However, it is completely indifferent whether they operate in the Middle East or in Europe (Mahzam, 2017).

Regular websites are also used to promote terrorist ideas. After 2001, there was a real flood of them on the Internet. Their number was estimated 
in 2008 at 6,000. Al-Qaeda was the leader here, the ringleaders of which appreciated the value of the Internet from the very beginning. The Islamic blogosphere supporting jihad was also created fairly quickly. Blogs and forums were often structured so that it was difficult to identify their authors (Seib, Janbek, 2011).

Facebook and Twitter are used by terrorists to support interpersonal relationships and to collect information. They support their members with the help of social media. It is also a good place to gather information about potential goals. Therefore, armies around the world are trying to control or determine the conditions for the participation of their own soldiers in these services (Seib, Janbek, 2011). Facebook also seems to be an ideal place to recruit and instruct new members of terrorist organisations. Al-Qaeda also used more advanced digital projects. It created digital clouds (e.g. sahab.net) that could be used as a place to recruit or train terrorists (Aboujaoude, 2012).

Undoubtedly, the use of digital space for terrorist actions is contributing to the dark side of the Internet, the so-called dark web (Seib, Janbek, 2011). Nevertheless, it shows the power of digital media as a communication tool that freely crosses national borders or political systems. On the one hand, they contribute to the rapid creation of mass movements giving the possibility of relatively independent communication. This also applies to countries that until recently were considered technologically backward. On the other hand, thanks to more and more specialised network tools, the digital world resembles one big "digital Panopticon". You just need to sit in the right place on the network to know almost everything about almost everyone. The United States is investing billions of dollars in collecting and analysing data. This is served by the activities of the National Security Agency (NSA) with large centres in the state of Maryland and Utah or the activities of the Israeli Unit 8200. Despite all tensions, the digital world still remains a platform that can be used to build and develop relationships in both interpersonal and intercultural aspects. Moreover, it seems that people have never had a tool of this scale before.

\section{Immigrants on digital platforms}

Immigrants coming to Europe, especially from the Middle East and Africa, are not digital illiterates. Often, culturally and mentally, they can be far from Europeans, while technologically they participate in the same digital world and in a similar way. That is why digital communication platforms can be the 
best place to get information, education, but also to influence or even control. Although we are already talking about technological borders, e-borders or simply about migration technology, it usually concerns the problem of controlling migrants and eliminating illegal migration (Meijer, Besters, 2011, pp. 3-4). Meanwhile, technology platforms offer much wider and more positive opportunities. It is all about education and value transfer. Importantly, such messages can reach immigrants before they leave their homeland.

The MASELTOV (Mobile Assistance for Social Inclusion and Empowerment of Immigrants with Persuasive Learning Technologies and Social Network Services) project was such an attempt to help integrate immigrants through the use of digital platforms, under which several programmes were implemented. The project was to develop and promote the use of those platforms by immigrants that have already been tested. This applies especially to language learning applications. Immigrants were encouraged to seize their opportunities. The British MoLeNET application was the largest project of this type. Smaller projects have also been created in other European Union countries: alpha-beta (Germany), Ensemble Project (Italy, France), MyVocab (Sweden), MobiDick (Denmark). In many other countries, projects have been created, the duration of which varied considerably (Kluzer, 2013).

The second group of projects were those related to job seeking. This is, for example, the Czech project Online Job Center for Foreigners or the French Societe Generale. The French initiative was taken by a private consortium and was primarily about providing opportunities for mobile money management, both in the home country and in the new immigrant country. In the case of platforms enabling finding work, not only smartphone, but also computer projects were created. They are addressed to both the first and second generation of migrants, e.g. projects like the German Surfen zum Job - Digitale Chancen auf dem Arbeitsmarkt. These types of projects were to help find a place on the labour market, create a portfolio for potential employers and better match their own competences to the labour market (Kluzer, 2013).

Another group of projects was intended to prevent the phenomenon of social exclusion among immigrants. The Dualia programme implemented in Spain used a mobile telephony system to provide remote translation services. It enabled communication for health and social care employees in particular. The project was addressed to immigrants who know little or no language of the host country (Kluzer, 2013).

An extremely interesting initiative was to create platforms for migrants on which they could express their opinions and thus increase their participation 
in the public sphere. The applications help to find your deputy or prepare for running a blog or Facebook account (Kluzer, 2013).

Similar applications were to support communication in two basic dimensions: interpersonal and intercultural. Immigrants need a lot of different information, even about everyday life, often immediately. Therefore, smartphones were recognised as the main tool for implementing the programme. Applications should be a useful aid above all in everyday life. The goal was also to motivate immigrants to learn and broaden their skills depending on the situational context ${ }^{7}$.

Studies of immigrants coming to Europe show that they also need digital tools to provide information before they leave their home country and are at the stage of making decisions. Research conducted among Syrian immigrants in 2015-2016 showed that they used information from social media both before setting off on a journey as well as while traveling to Europe. Practically, the only obstacle was the fear of government control of the media. Information coming directly from colleagues or from a network of well-known friends was considered more reliable. In other situations, migrants used various strategies to verify information (Dekker, Engbersen, Klaver, Vonk, 2018).

Research carried out by Dekker, Engbersen, Klaver and Vonk among Syrian refugees has shown that they most often use smartphones. Using this tool, they can use the information and communication potential of the network to build intelligent migration strategies. Information is assessed differently in terms of reliability. There are those that have a broad transmission from governments and organisations dealing with migration, and those with a narrow reach from friends or relatives. One can speak of a kind of "information uncertainty" of migrants, especially during the decision-making period and while moving to the destination country. This is largely due to the importance of decisions being taken. Sources built on direct bonds are in this situation assessed as much more reliable than the official ones. The least reliable is information from unknown sources often rated as rumours.

However, some countries may undermine migrants' confidence in social platforms or tools such as smartphones. This is about checking telephones of migrants on an increasing scale, especially those who have applied for asylum. In early 2016, the Dutch Security and Justice Inspectorate conducted an analysis of checking data from smartphones. It decided that this should

7 Source: Project. http://www.maseltov.eu/Project\%20«\%20MASELTOV.html (2.01.2020). 
be tightened. It was ordered to improve the quality of school staff, equipment and to develop new procedures (Steiffer, Wörmann, 2016, p. 38). This can lead to more cautious use by migrants of some useful applications for them for fear that this will be a way for government agencies to collect information about them (which, for example, deal with combating human smuggling). Despite this, it will probably not significantly affect the level of migrants' use of digital media. However, strategies of their use will probably change and this should be the subject of further research.

The development of new technologies in Africa as well as in the Middle and Far East, their increasing use and range among the citizens of these regions of the world shows that they are becoming "digital natives", just like the inhabitants of Europe or North America. Migrants arriving from these regions of the world are efficient in using digital platforms and using them to achieve their goals. There are three stages in which migrants specifically engage digital platforms:

- stage of decision making;

- stage of migration to the destination country;

- stage of acclimatisation in the destination country.

Especially at the last stage, we try to help migrants through various tools, usually in the form of applications for smartphones. They are primarily to help learn the language, find a job and eliminate the effects of "social exclusion". There have been many such projects in Europe. However, there are almost no tools that would significantly affect the activities of migrants undertaken in the first two stages. At the first stage, migrants often over-optimise their options by neglecting risk. They have no information about it and there is no data where they can get help in their home country. Often, they receive euphoric information from European media that is difficult to critically assess. Also the second stage would require digital support, primarily in terms of calling for or getting help. The issue of using digital media to help migrants still requires research so that they can be properly "profiled" and their intended and not accidental results can be achieved.

\section{Bibliography}

Aboujaoude, E. 2012. Wirtualna osobowość naszych czasów. Mroczna strona e-osobowości. Kraków: UJ.

Benedykt XVI. 2009. Nowe technologie, nowe relacje. Trzeba rozpowszechniać kulturę szacunku, dialogu i przyjaźni. Orędzie na 43 Światowy Dzień 
Środków Społecznego Przekazu. https://opoka.org.pl/biblioteka/W/WP/ benedykt_xvi/przemowienia/massmedia2009_24012009.html (8.01.2020). Castells, M. 2013. Sieci oburzenia i nadziei. Ruchy społeczne w erze internetu. Warszawa: Wydawnictwa Naukowe PWN.

Dekker, R., Engbersen, G., Klaver, J. and Vonk, H. 2018. Smart Refugees: How Syrian Asylum Migrants Use Social Media Information in Migration Decision-Making. Social Media + Society. https://journals.sagepub.com/ doi/full/10.1177/2056305118764439 (13.01.2020).

Dijstelbloem, H., Meijer, A. i Besters, M. 2011. The Migration Machine. In: Dijstelbloem, H. and Meijer, A. eds. Migration and the New Technological Borders of Europe. Hampshire: Palgrave MacMillan, pp. 1-21.

Fenton, S. 2016. Angela Merkel Selfie With Syrian Refugee Goes Viral After He Is Wrongly Named as Brussels Bomber. Independent 29 March. https://www.independent.co.uk/news/world/europe/syrian-refugees-selfie-with-angela-merkel-goes-viral-after-he-is-wrongly-named-as-brusselsbomber-a6958371.html (8.01.2020).

Kibble, D. G. 2016. Dabiq, the Islamic State's Magazine: A Critical Analysis. Middle East Policy. 3 (23), pp. 133-143.

Kluzer, S. 2013. Deliverable Report D2.1. "Imigration and ICT in Europe”. http://www.maseltov.eu/Dokuments/PU_MASELTOV_D2.1_UOC_201207-16_Immigration-and-ICT-in-Europe_final.pdf (13.01.2020).

Kuuire, J.A. 2019. Africa Digital Summit +Expo. https://technovagh. com/2019/08/27/the-2019-africa-digital-summit-and-expo-seeks-tounlock-africas-digital-future (8.01.2020).

Lee, M.Y. 2006. The Internet in Politics: Democracy in E-government in Taiwan. In: Voltmer, K. ed. Mass Media and Political Communication in New Democracies. London - New York: Routledge, pp. 168-185.

Lister, M., Dovey, J., Giddings, S., Grant, I. and Kelly, K. 2009. New Media. A Critical Introduction. Milton Park: Routledge.

Łuszczek, K. 2015. Wolność i kontrola w internecie drugiej fali. Tychy: Maternus Media.

Mahzan, R. 2017. Rumiyah - Jihadist Propaganda \& Information Warfare in Cyberspace. Counter Terrorist Trends and Analyses. 3 (9), pp. 8-14.

Nyavi, G.A. 2019. Africa Digital Awards Launched in Accra. https://www. graphic.com.gh/news/general-news/ghananews-africa-digital-awardslaunched-in-accra.html (8.01.2020).

Orhan, E. 2017. Tureckie media za rząów Recepa Tayyipa Erdoğana (2003-2014). Toruń: Wydawnictwo Adam Marszałek. 
Seib, Ph. and Janbek, D. M. 2011. Global Terrorism and New Media. The Post - Al Qaeda Generation. New York: Routladge.

Shapshak, T. 2019. Africa's Mara Group Launches Phone Factories in Durban, Kigali. Forbes 31 October. https://www.forbes.com/sites/tobyshapshak/2019/10/31/africas-mara-group-launches-phone-factories-in-durban-kigali (13.01.2020).

Steiffer, L. Wörmann, H. 2017. 2016 Annual Policy Report. Migration and Asylum in the Netherlands. Rijswijk: Ministry of Security and Justice.

Wawrzyńczak, A. 2014. Dżihad online, czyli jak terroryści wojuja w Internecie. https://wiadomosci.wp.pl/dzihad-online-czyli-jak-terrorysci-wojujaw-internecie-6027713017107073a (13.01.2020).

Wolman, D. 2008. Cairo Activists Ude Facebook to Rattle Regime. Wired 20 October. https://www.wired.com/2008/10/ff-facebookegypt (8.01.2020).

\title{
Technology as a platform for intercultural communication exemplified by the migration from Africa and the Middle East
}

\begin{abstract}
The text concerns the possibilities of intercultural communication offered by modern digital media. It analyses the possibilities of its development on the example of the problem of mass migration to Europe. It concerns countries that are often much less economically developed than European or American countries. However, as the data on the development of technology in these countries show or its use shows (e.g. in mass social movements from the turn of the first and second decades of the 21st century), the citizens of these countries are not "digital illiterates". The same applies to migrants coming from these countries. That is why digital media, and especially tools such as smartphones, can be used in intercultural dialogue and to help migrants at various stages of their migration journey. This applies especially to the stage of decision making, migration to a selected country or adaptation in the destination country. A number of such aids were created (primarily smartphone applications), which, however, do not apply equally to all three stages of a migrant's life.
\end{abstract}

Keywords: new technologies, migration, intercultural communication, smartphone 